\title{
Housing Allowances in Comparative Perspective
}

\author{
Marietta E. A. Haffner
}

Published online: 21 December 2008

(C) The Author(s) 2008. This article is published with open access at Springerlink.com

Peter A. Kemp (ed.), Bristol, The Policy Press, University of Bristol, 2007, pp. xv +295, ISBN 9781861347545 Hardcover

In many advanced Northwestern European welfare states, a shift occurred in the second half of the last century from supply-side to demand-side subsidies, the most common form being called housing allowances (HA), though they exist under different names. Nowadays their aim is to ensure that homes of reasonable quality are affordable to lower-income households (income dependency). In countries such as Germany, the Netherlands, Sweden, the US and Australia, HA have become a key instrument in housing policy, now that supply-side subsidies have been reduced or abolished.

Ten years after Peter Kemp's (1997) international comparison of HA, the many changes warrant a new publication. Both books acknowledge that HA are part of a broader welfare system, and both use welfare system classifications to justify the selection of countries to be compared. The 2007 book adopts the welfare regimes of Esping-Andersen (1990) when classifying five of the ten countries as a liberal regime (Australia, New Zealand, Canada, US and Great Britain) and two each as conservative (France and Germany) and social democratic regimes (Netherlands and Sweden). In order to include a country in transition to a market economy, the new book contains a chapter on the Czech Republic, though it is not classified according to a welfare regime.

The 2007 book is an edited volume, with authors from each country taking responsibility for the national profiles; chapters 2 through 11 focus on the ten countries. Chapter 1 comprises the introduction, while chapter 12 presents the editor's conclusions, mainly about the "Housing allowances in advanced welfare states". In chapter 12, the Czech Republic is not fully integrated in the discussion, being covered mainly in the tables and the accompanying text.

When authors write about their own countries, they often know the situation by heart and are able to make clear what is important in policy and practice there. This book delivers

M. E. A. Haffner ( $\square)$

OTB Research Institute for Housing, Urban and Mobility Studies, Delft University of Technology, Jaffalaan 9, 2628 BX Delft, The Netherlands

e-mail: m.e.a.haffner@tudelft.nl 
exceptionally thorough descriptions. The other side of the coin, however, is that topics get a different emphasis in different contexts (e.g., take-up).

Also, when the structure is not stringently imposed on each chapter, not all questions can be answered for all countries. The three approaches to HA in social assistance is a case in point. Social benefits would partially include housing costs (Australia, the Netherlands and New Zealand), would be enhanced to include housing costs (Canada, Germany, Sweden and British homeowners) or would exclude housing costs (tenants in Britain). Yet it remains unclear where France, the US and the Czech Republic fit in.

The emphasis on difference topics is mirrored in the use of different titles to organize the national profiles. Most chapters adhere to the same outline, first sketching the development in the housing policy and social security context of HA and then describing the role, design and the impact of the HA. The country chapters conclude with a review of topics such as policy debates, reforms, (adverse) impacts, the future and/or design dilemmas of HA. Yet the chapter on the Czech Republic ends with a brief comparison of the schemes in Poland, Slovakia and Estonia.

This edited edition clearly shows how differently HA schemes are designed across countries. One difference concerns the formal coverage of the tenures: will the scheme be designed as a generic allowance open to all who qualify (entitlement) whether they are a social tenant, a private tenant, an owner-occupier or a cooperative occupier? Such a generic system exists in the Czech Republic, France, Germany, Quebec (Canadian province) and Sweden (only for households with children, young households and pensioners). Even though HA are available in all tenures in these countries, more tenants than homeowners are actual beneficiaries. In Britain and the Netherlands, HA are aimed at tenants; in the US they are meant to help social tenants move into the private rental sector but are not an entitlement. There are also countries with divergent systems for different tenures, as in Britain (see above). In Australia, Canada and New Zealand, alongside HA in the private rental sector (only in some of Canada's federal states), there is an implicit HA. It works through individual rent setting in the social or public rental sector based on the beneficiary's income and other characteristics.

Another design difference influencing coverage is whether entitlements are regularly indexed. In Canada, Germany, New Zealand and Sweden inflation indeed regularly reduces the number of beneficiaries and thus restricts the coverage of the scheme. For example, in Sweden the number of recipients decreased from 365,000 in 1997 to 214,000 in 2004 because of non-indexation.

Adding up the impact of the rules of the schemes and take-up shares, the number of households receiving HA runs from two percent or less of all households in Germany, Canada and the US to $20 \%$ or more in Sweden (20\%) and France (about one in four households). Of course, these types of data say little about the actual impact on housing expenditure of recipients in comparison to those of non-recipients, but the national profiles do give information on this point.

As the case of Germany shows, the share of recipients does not tell the whole story when "the wider income package provided by welfare states to meet social risks or other income protection goals" (p. 282) is included. There, 9\% of households had received HA in 2004, while this share decreased to $2 \%$ in 2005 . This decline resulted from a change in the way target groups were defined. HA was included in the respective social benefit (see above) for all employable people as of 2005. So even though large numbers of people are involved, such a change may turn out to be not much of an actual change when assistance for HA is considered by itself. After all, what's in a name? Such interrelations between social benefit and HA could explain why the editor states that "income-related housing allowances appear to be 'relatively autonomous' from welfare regime types" (p. 11). 
Because each country has its own history of housing finance and subsidization as well as of social security policies, the policy debates differ. For the Czech Republic, it is argued that basing HA on notional rents instead of actual rents paid by tenants is a "major failure" of the scheme (p. 250). The notional rent as it is applied in the Czech Republic does not take account of regional differences in housing costs and between tenures; e.g., private rents are much higher than regulated rents.

Contrary to the Czech Republic, the notional rent that Britain has been experimenting with in private renting takes account of regional differences, a design feature that is also applied in Germany and the US. When the editor states that "other countries may follow the British example" (p. 282), he implies they might be following a unique feature of the British experimental HA. It is the incentive for the tenant to also make a conscious trade-off between quality and price when actual rent is lower than notional rent. In Britain the proposal is to share this difference with the tenant once the scheme is introduced nationally. In the German and US profiles, nothing is mentioned in this regard, except for when it is the other way around: the tenant will get assistance for the notional rent, paying for the difference between notional and actual rent.

A topic still open to discussion is the question of how well an HA scheme reaches its aims (in its respective context). The Swedish government is planning a review on this point, as is the government of New Zealand. For the US, some surprise is expressed on how little is known for certain about reaching the goals.

Many more points of debate are raised in the country chapters, such as how to integrate the systems of support in private and public renting and whether to expand the not-for-profit sector (Australia). For instance, work disincentives and over-consumption are important topics, although few unanimous research findings about these effects are available.

What this edited edition shows quite well is how very difficult it is to make an integral analysis of HA in welfare regimes and to compare HA across countries. Chances are that analysis of the HA schemes will remain a partial analysis. This is suggested here by the fact that information on welfare regimes is mainly presented in the first and last chapter, not in the ten country chapters. For a future book-which is already desirable in view of the data-the challenge will be to find a mode that goes beyond a very thorough description.

Open Access This article is distributed under the terms of the Creative Commons Attribution Noncommercial License which permits any noncommercial use, distribution, and reproduction in any medium, provided the original author(s) and source are credited.

\section{References}

Esping-Andersen, G. (1990). The three worlds of welfare capitalism. Cambridge: Polity.

Kemp, P. A. (1997). A comparative study of housing allowances. London: H.M. Stationery Office. 